https://doi.org/10.18485/iipe_ru_sr.2020.ch5

\title{
THE IMPACT OF THE ISSUE OF KOSOVO AND METOHIJA ON SERBIAN - ALBANIAN RELATIONS
}

\begin{abstract}
Yuliya Bulannikova ${ }^{1}$
Abstract: The article considers the current state of Serbian - Albanian relations by 2020. It gives an overview of the importance of Albania's position on the issue of Kosovo and Metohija for the deepening of bilateral relations as well as the Serbian strategy in the region, analyses the main contradictions in Belgrade - Tirana relations, and identifies the features of Serbian diplomacy towards Albania. The chronological scope of the study is limited to 2008-2020, which is due to the emphasis on the analysis of the current disagreements between the two states in connection with the recent developments in Kosovo and Metohija. The article also deals with the changing situation in the Western Balkans in the context of the full incorporation of all countries into the European and Euro-Atlantic integration institutions. This article examines the internal and external factors of a certain degree of Serbian - Albanian relations, the positions and actions of those who support and those who oppose the cooperation of the two countries not only at the bilateral but also at the regional level.

Keywords: Serbia, Albania, issue of Kosovo and Metohija, Western Balkans, bilateral relations, EU enlargement, stabilisation and association process.
\end{abstract}

Serbian - Albanian relations were affected by Albania's 2008 recognition of 'Kosovo' independence. Albania supported the 1999 NATO intervention against the Federal Republic of Yugoslavia and the policy of expanding the number of countries extending diplomatic recognition to 'Kosovo'.

${ }^{1}$ Candidate of Sciences (History), Associate Professor of the Department of European and American Studies, School of International Relations, MGIMO MFA of Russia. E-mail: moivp@yandex.ru 
Serbia protects its sovereignty and territorial integrity and has launched the process of revocation and suspension of recognitions of the unilaterally declared independence of 'Kosovo'. Currently, Serbia's EU accession is conditioned with the rule of law and economic reforms, as well as the normalization of relations with Pristina via the EU-facilitated dialogue. The finding of a comprehensive, viable political solution to the issue of Kosovo and Metohija is a top national priority of Serbian policy, with obvious significance for Serbian - Albanian relations and peace and stability in the wider region. Serbian First Deputy Prime Minister and Minister of Foreign Affairs Ivica Dačić stated that the project to create an independent state of 'Kosovo' was a big mistake made by a part of the international community, as well as that the states could not be created by unilateral decisions (Dačić, 2020).

'Kosovo' declaration of independence on 17 February 2008 met a divided international response. Some 23 EU Member States recognised 'Kosovo' as an independent state. The five non-recognising states are Spain, Cyprus, Greece, Romania, and Slovakia. Serbia is trying, on the one hand, to preserve its territorial integrity and sovereignty violated by the independence of 'Kosovo' and, on the other, to develop the concept of a multi-vector foreign policy and multiple strategic partnerships.

The bilateral Serbian - Albanian political dialogue has almost stopped. Since 2014 the government of Prime Minister Aleksandar Vučić has tried to improve relations with its neighbours, particularly with Albania. The first visit of Albanian Prime Minister Edi Rama to Serbia in November 2014 was deemed historical. At the press conference of the two leaders, Rama declared that the countries"have two entirely different positions on Kosovo, but the reality is one and unchangeable"(Rama, 2014). Belgrade and Tirana were trying to overcome the dominant differences between the two countries concerning the status of Kosovo and Metohija, to strengthen economic cooperation and further improve the status of minority communities. When it comes to relations with neighbours, Tirana often emphasizes the position of Albanians in North Macedonia, southern Serbia and Montenegro and repeatedly requires the copying of legal guarantees for the status of Serbs in 'Kosovo' for the Albanian municipalities of Preševo, Bujanovac, and Medveđa (the Preševo Valley). The two Prime Ministers have intensified meetings to overcome barriers between the two countries and made efforts to boost cooperation. 
Serbia is active in its relations with Albania, fully respecting the principle of non-interference in internal affairs. The two countries' governments have expressed the political will to settle pending issues and further promote bilateral relations in general and of the evident need to enhance cooperation in the framework of the European integration process in particular.

A series of statements by Albanian Prime Minister Edi Rama, the "head" of the self-proclaimed independent 'Kosovo' Hashim Thaci, and the "head" of the south Serbian municipality of the Presevo Valley (mainly populated by Albanians) Jonuz Musliu, regarding the redrawing of borders in the Balkans (to implement the Greater Albania project), raised particular concern in Serbia. However, any projection for a de jure unification prior to full accession of Albania and 'Kosovo' in the European Union is not realistic because of constitutional obstacles and opposition of international actors, but also because of the resistance of the mainstream political leaders in Albania and 'Kosovo', which may see any potential unification as a threat to their personal power (Kalemaj, 2014, p. 37).

The European Union (primarily Germany) and indeed the United States, perceive the improvement of relations between Belgrade and Pristina as a potential solution to the numerous latent tensions in the Western Balkans (Đukanović, Simić, Zivojinović, 2013, p. 108).

Serbian President Aleksandar Vučić, participating in the leadership panel of the 15th Bled Strategic Forum, pointed out that the political status of Kosovo and Metohija will be discussed under the auspices of the EU, and economic issues with the United States (Vučić, 2020). President Trump suggested a formula to do economics first and let the politics follow the economics' (Trump, 2020).

On 3-4 September Serbian President Aleksandar Vučić and 'Kosovo Prime Minister' Avdullah Hoti met at the White House for talks on economic relations and committed to the economic normalization. President Trump announced a historic commitment (Trump, 2020). By focusing on job creation and economic growth, Belgrade and Pristina were able to reach a real breakthrough on economic cooperation across a broad range of issues such as the opening of border crossings, the US investment in both 'Kosovo' and Serbia, and deals between 'Kosovo' and Serbia on recognizing each other's diplomas and licenses. One part of the agreement was the freezing on the recognition and de-recognition campaigns during 2021. President Vučić pointed out that the normalization of economic relations between 
Belgrade and Pristina was a huge step forward. However, for Serbia, it is very important to have a unified economic zone, the entire Western Balkans (Vučić, 2020).

Meanwhile, Serbia has committed to opening a commercial office in Jerusalem this month and to move its embassy to Jerusalem by July. Pristina and Israel have agreed on the normalization of ties and the establishment of diplomatic relations.

On 7th September, on the occasion of the continuation of the EU Facilitated Dialogue between Belgrade and Pristina, President Aleksandar Vučić and Prime Minister Avdullah Hoti confirmed to the EU High Representative for Foreign Affairs and Security Policy/Vice-President of the European Commission, Josep Borrell that they attach the highest priority to EU integration and to continuing the work on the EU-facilitated BelgradePristina dialogue, which is a key element of their respective EU paths. They also committed to redoubling their efforts to ensure further EU alignment in accordance with their respective obligations (Vučić, Hoti, 2020).

Miroslav Lajčak, the EU's special representative for Belgrade-Prishtina dialogue said:

They confirmed that they attach the highest priority to the EU integration and to continuing the work on the EU-facilitated Belgrade-Pristina Dialogue.

We spoke about economic cooperation and missing and displaced persons - the topics which were opened in our last high-level meeting. And I am happy to announce that we made full progress on the discussions.

We also discussed for the first time, as part of the negotiations of a legally binding comprehensive agreement, arrangements for non-majority communities and also the settlement of mutual financial claims and property. This was the first exchange that allowed us to define the next steps in our discussions.

(Lajčák, 2020).

Russia insists on the resolution of the Kosovo issue exclusively based on the agreements that will have to be subsequently endorsed by the UN Security Council and will accept any solution that will be agreed upon by Belgrade and Pristina.

Currently, both international and local pressure is growing on Belgrade and Pristina to define their relations through a comprehensive agreement 
on the normalization, with a view to achieving a visible and sustainable improvement of mutual relations. Although Serbian and 'Kosovo' representatives confirm, in principle, their commitment to the full normalization of relations, they have differing and often conflicting views of this ultimate goal. Belgrade and Pristina often have different views of the time-frame needed for this agreement to be reached. EU membership is a common goal for both Belgrade and Pristina. Establishing good relations and resolving open disputes are absolute prerequisites for this goal to be achieved.

At the turn of the XX and XXI centuries, the Balkan region was included in the sphere of influence of only the one external force - the collective West. The West's influence in the region is currently almost unchallenged, which explains the ongoing homogenization of the Balkans due to its gradual integration into the EU and NATO and the adoption of common standards of foreign and domestic political behaviour. The USA and the EU act as an arbiter in disputes between the Balkans states, quite often contradicting public sentiment in the region and states' interests in foreign policy and economy. Thus, the concessions of Belgrade and Pristina in the process of the EU-initiated dialogue were widely rejected by both Serbs and Kosovo Albanians. The Brussels Agreement (April 2013) was reached only after a demand to overcome differences in two weeks (Кириллов, Путинцев, 2020, c. 60-61).

One of the priorities in the foreign policy of Serbia and Albania is regional cooperation which is a cornerstone of the EU's policy framework for the Western Balkans - the stabilisation and association process (SAP). The countries and the EU consider enhanced regional cooperation to be a key factor for establishing political stability, security, and economic prosperity.

The first impetus for institutionalizing regional cooperation was given by the end of the Cold War. In the context of the easing of international tensions, development of the Helsinki process, and the approval of a cooperative model of relations between the states of two opposite social systems, the Central European Initiative (CEI) was established in 1989. The appeal to common interests has underscored most regional cooperation schemes since the 1995 Dayton peace (Bechev., 2004, p. 5). The EU and the USA created and developed a number of regional groupings as stabilization mechanisms. They subsequently became an instrument of the Central and 
Southeastern European countries' adaptation to development conditions in the European Union and NATO.

In the framework of the EU integration process, Serbia and Albania pay special attention to the development of regional cooperation, particularly through regional initiatives: the South East European Cooperation Process (SEECP), the CEI, the Adriatic and Ionian Initiative (AII), the Central European Free Trade Agreement (CEFTA 2006), the Regional Cooperation Council (RCC), the Berlin process (BP) and the Western Balkans Fund (WBF). The areas of security, trade, energy and transport are among those where regional cooperation is the most substantial. The leaders of Serbia and Albania urged regional cooperation to establish a common market for local and foreign investors. Prime Minister Rama said that 'our markets are too small, separated from each other in a world that from the competition viewpoint is becoming tougher' (Rama, 2016). In 2019 Serbia, Albania and North Macedonia signed the declaration of intent to establish the free movement of people, goods, services and capital between the three countries (the so-called "mini-Schengen" regional cooperation initiative).

Meanwhile, the development of regional cooperation is hindered by the lack of developed infrastructure and communications, the lack of funding for multilateral projects and initiatives, the low degree of economic complementarity between states, and the legacy of ethnopolitical conflicts.

Economic relations between Albania and Serbia have improved in recent years. There is a free trade agreement that provides significant trade preferences for bilateral trade between Serbia and Albania (Kosovo and Metohija is a separate customs territory, as defined by UNSCR 1244). They are members of the Revised Central European Free Trade Agreement signed in 2006 (CEFTA 2006). However, the dynamics and structure of trade between the two economies are low and unbalanced.

In the 2000s, trade flows between the two countries had an increase because of the application of trade preferences contained in free trade agreements (Bjelić, Dragutinović Mitrović, 2016, p. 5). In the 2010s, trade flows were consistent. Serbia had a trade surplus of 110 million Euros in 2019. The exports from Serbia to Albania during 2019 amounted to 158 million Euros, while imports were 48 million Euros. Albania's balance of trade with Serbia has been negative over the years. The commodity groups making the biggest bulk of Albania's imports from Serbia are "minerals, fuels and electricity" (the main commodity is electricity) and "food, tobacco and 
beverages" (the main commodity is grains). Serbia is currently Albania's sixth-largest trading partner, while Albania is not even in Serbia's top twenty partners for trade exchanges.

The trade in services between Serbia and Albania started to rise steadily in 2010. It was around 16 million Euros in 2018. Serbia foreign investment in Albania is at a mere 40 million Euros, with potential for investment in construction, energy, and transport tourism, which is emerging as one of Albania's most promising sectors.

In 2016 Tirana-based joint Albania-Serbia Chamber of Commerce was launched and expected to give a boost to trade exchanges and investment between the two countries. Irrespective of political differences, Serbian President Aleksandar Vučić and Albanian Prime Minister Edi Rama called on the business communities to invest in the two countries. Some 100 Serbian SMEs operate in Albania, mainly in construction, industry, tourism and services, while the number of Albanian companies in Serbia is estimated lower. The states launched the direct Belgrade-Tirana flights by Air Serbia carrier and the extension of the Albania-Kosovo highway to Nis.

Bilateral resistance factors of the low level of trade are beyond the trade regime conditions and dependent on infrastructural quality, product structure of exports, and political factors (Bjelić, Dragutinović Mitrović, 2016, p. 12). There needs to be trust between Belgrade and Tirana to take cooperation and collaboration to the next level. The economy is serving as a meeting point for Serbia and Albania and should be seen as the cooperation that will spill over to other areas (Balla, Ejdus, Llubani, 2013, p. 59).

Cultural diplomacy and its accessories play an important role in increasing Serbia's influence in the region. Cultural cooperation between Serbia and Albania is expected to strengthen bilateral relations and contribute to the common goal of EU integration. In 2017, the Serbian and Albanian Ministers of Culture signed the cultural cooperation agreement. Regional Youth Cooperation Office (RYCO) was established to increase cooperation in education, culture, youth and sport.

Civil society organisations are also playing a key role in the improvement of Serbian - Albanian relations. The Albanian Institute for International Studies and the European Movement Serbia have established a joint Centre for Albania-Serbia relations to boost relations between the two countries and overcome stereotypes. According to the results of the 2014 survey taken 
by the Albanian Institute for International Relations (AIIS), Albanians consider the 'historical hostility between the two nations' as one of the key obstacles in developing bilateral relations (Cela, 2015, p. 10). Civil society contacts are at an advanced stage.

Serbia's relationship with Albania experiences occasional tensions, ranging from improvement to a deterioration. Serbian-Albanian ties were strained when Tirana recognized 'Kosovo' independence in 2008 and became one of Pristina's strongest external supporters. Although some of the goals of Serbia and Albania are complementary, others contradict each other. The probability of overcoming Serbian - Albanian disagreements about the issue of Kosovo and Metohija, while maintaining the positions taken by both sides today, remains low. The statements by Albanian Prime Ministers Sali Berisha and Edi Rama and the "head" of the self-proclaimed independent 'Kosovo' Hashim Thaci on their readiness to join forces in a single Greater Albania state do not contribute to the development of Serbian - Albanian relations and finding a compromise solution for the issue of Kosovo and Metohija. At times disputed issues seem to dominate relations and bring them back to the past.

However, as long as the countries share the same foreign political goal of EU membership, the process of European integration in itself is a stabilizing and developmental tool of political, cultural, economic, and tourism bilateral cooperation. The EU and NATO enlargement in the Balkans has eliminated (promptly or proactively) the existing and re-emerging conflicts between the countries of the region and has artificially overshadowed outstanding issues. In the context, relations between Serbia and Albania require more goodwill and permanent efforts of the political elites in order to actually eliminate obstacles and build relations on mutually beneficial foundations.

\section{References}

Predsednik Vučić na 15. Bledskom strateškom forumu [President Vučić at the 15th Bled Strategic Forum] (2020, 31 avgust), retrieved from https://www.predsednik.rs/lat/pres-centar/vesti/predsednik-vucicna-15-bledskom-strateskom-forumu. Accessed 1 September 2020. 
Albania's Impact in the region in the Albanian-speaking Areas (P. 68). (2018). Tirana, Friedrich-Ebert-Stiftung.

Balla, A., Ejdus, F., Llubani, M. (2013). Albania and Serbia: Perceptions and Reality. Retrieved from http://www.bezbednost.org/upload/document /albania_and_serbia_-_perceptions_and_reality.pdf

Bechev., D. (2004). Contested Borders, Contested Identity: The Case of Regionalism in South East Europe, Journal of Southeast European and Black Sea Studies, Vol 4, no 1 (Winter 2004), pp. 77-96.

Bjelić, P., Dragutinović Mitrović, R. (2016). The Albania-Serbia Trade Exchange and its Potentials. Retrieved from http://arhiva.emins.org/ uploads/useruploads/projektiEnpdf/The-Albania-Serbia-TradeExchange-and-its-Potentials-2016.pdf

Cela, A. (2015). Albania-Serbia relations in the eyes of the Albanian Public 2015. Retrieved from http://library.fes.de/pdf-files/bueros/albanien/ 12302.pdf

Đukanović, D., Simić D., Zivojinović D. (2013). Serbia and its neighbors: continuity of old and/or new policy, The Review of International Affairs, Vol. LXIII, No. 1151, pp. 104-118.

European External Action Service. (2020, September 7). Belgrade-Pristina Dialogue: Remarks by the EU Special Representative Miroslav Lajčák after the high-level meeting, Brussels.

European External Action Service. (2020, September 7). Belgrade-Pristina Dialogue: Joint Statement by President A.Vučić and Prime Minister A.Hoti ahead of their meeting in Brussels.

Joint Centre for Albania - Serbia Relations. (2016). Albania and Serbia towards a common future in the European Union. AIIS Report. http://arhiva.emins.org/uploads/useruploads/projektiEnpdf/DurresForum-Report-AIIS-may-2016.pdf

Kalemaj, I. (2014). Albanian-Kosovo relation: Quo Vadis? Tirana, FriedrichEbert-Stiftung. Retrieved from http://library.fes.de/pdf-files/bueros/ albanien/11322.pdf

Permanent Mission of the Republic of Serbia to the United Nations. (2020, April 24). Statement by H.E. Mr. Ivica Dačić, First Deputy Prime Minister and Minister of Foreign Affairs of the Republic of Serbia, New York. 
Robinson. M. (2014, November 10). Kosovo comes between Serbian, Albanian leaders at historic meeting, retrieved from https:// www.reuters.com/article/us-serbia-albania-kosovo/kosovo-comesbetween-serbian-albanian-leaders-at-historic-meeting-idUSKCN0 IU16W20141110 Accessed 3 August 2020.

Statistics Office of Republic of Serbia. (2019). Exports and imports, by country of destination/origin, retrieved from https://www.stat.gov.rs/ en-us/oblasti/spoljna-trgovina/ Accessed 28 July 2020.

The Challenges of Serbia's Foreign Policy - Collection of Papers (P. 95). (2015). Belgrade, Friedrich-Ebert-Stiftung.

White House. (2020, September 4). Remarks by President Trump, President Vučić of Serbia, and Prime Minister Hoti of Kosovo in a Trilateral Meeting, Washington D.C., USA.

Кириллов, В., Путинцев, И. (2020). Балканы в 2020-е гг.: гомогенизация региона под влиянием Запада и роль России [The Balkans in the 2010s: Homogenization of the Region under the West's Influence and the Role of Russia], Современная Европа, №1, c.59-68. 